\title{
Disrupted Parenthood in Caryl Phillips's The Final Passage
}

\author{
Anastasiia Fediakova \\ Charles University, Prague, Czech Republic
}

In his debut novel The Final Passage, first published in 1985, Caryl Phillips (dis)connects the English and the Caribbean spaces simultaneously imposing this inbetweenness onto his continuously misplaced characters. This paper explores the novel through the lens of disrupted parenthood, demonstrating that the ties between the family members mirror the inability of the protagonists to belong or to sustain relationships. By applying a postcolonial framework and including both canonical and recent texts produced in the field, this paper analyses how racial labels and assumptions weaken fragile bonds and further displace the characters as it also attempts to fill a gap since aspects of distress and breakdown are often neglected in literary criticism. Finally, given the background of the West Indies, the paper incorporates social and anthropological works dedicated to the region and connects Phillips's narrative to the stories of migrants in contemporary Britain.

\section{Keywords}

Caribbean literature; West Indian families; Caryl Phillips; mother-daughter relationship; colony and metropole; dysfunctional parenthood

Caryl Phillips's debut novel The Final Passage, published in 1985, introduces and discusses aspects of diaspora, migration and belonging, the very themes which continued to reappear in Phillips's later works, both fiction and nonfiction. However, while in his more recent texts the author gradually stepped away from the boundaries of gender, nation and class, The Final Passage remains a disturbing account of the migrant experience, portraying the characters of the narrative trying to reach beyond the borders of one country in their continuous search for space and place. In academic studies, this novel is also analysed in connection with manhood and postcolonial shame (Bewes, Smith) 
as well as with the experience of travelling and fitting in (Kato, Goddard). Nevertheless, although this current paper relies on previous research, it explores a somewhat different direction by focusing on the depiction of parenthood which often appears to be distorted, constantly pointing to an inability to connect and to emotional distress.

According to a study conducted in 2006, African-Caribbean people who live in the UK "show very high incidences in schizophrenia and mania in both men and women, in all age groups" which is nine times higher than in the white British population; these incidences are even higher in the second generation of African-Caribbean migrants (Ledent 63). Another piece of research conducted in 2017 by Maryland Psychiatric Research Center in the East of England revealed that "ethnic minority groups experience elevated rates of first-episode psychosis" (Kirkbride). However, even before any of these facts were recorded and analysed, they had been expressed through fiction, including not only in the works of Phillips but also those of Jean Rhys and Zadie Smith. In that regard, The Final Passage could be viewed as a signal of the problematic life of the Caribbean diaspora long before the official statistics. Therefore, by concentrating on the theme of dysfunctional relationships, this paper explores issues which remain relevant in today's Britain and it additionally attempts to fill a gap, i.e., that aspects of anguish, psychosis and breakdown are often neglected in literary criticism (Ledent 3-6).

In order to provide a pathway to the topics of mental aberration in Caribbean writing in relation to The Final Passage, this paper brings in the aforementioned Madness in Anglophone Caribbean Literature by Bénédicte Ledent and Alison Klein's Anglophone Literature of Caribbean Indenture: The Seductive Hierarchies of Empire. In addition to these recent texts, this paper also incorporates the ideas in canonical works by Frantz Fanon and Anne McClintock coupled with two books by Bill Ashcroft and his colleagues, namely Key Concepts in Post-Colonial Studies and The Empire Writes Back. Whereas Fanon's Black Skin, White Masks is employed in order to gain insight into the theme of interracial unions, McClintock's Imperial Leather helps to uncover how a territory is possessed through a female body, particularly in connection with parentchild relationships. Given the importance of the Caribbean background, in addition to these texts, the paper incorporates a selection of social and anthropological studies which concentrate on Caribbean family patterns and the role of women such as My Mother Who Fathered Me: A Study of the Families in Three Selected Communities of Jamaica by Edith Clarke and Children's Rights: Caribbean Realities edited by Christine Barrow. 
As for the parts of the novel dedicated to London, this paper relies on the collection of essays Imaginary Homelands by Salman Rushdie, a well-known postcolonial author who supports ethnic minorities and advocates against racial discrimination. The majority of works in Imaginary Homelands reflect the deteriorating tension in British society throughout the 1970 s and 1980 , the decades which followed the period described in The Final Passage. Finally, in order to connect Phillips's novel with the stories of contemporary migrants, this paper also incorporates extracts from This Is London: Life and Death in the World City, Ben Judah's 2016 account of stories of intertwined fates of diaspora communities in London.

Stepping away from secondary sources and returning to the discussion of disrupted relationships, it needs to be emphasised that the topic of parenthood in The Final Passage is an umbrella theme as it is interconnected not only with the family models in the Caribbean as a whole but also with female dependency, the constant echo of the colonial era which reverberates with racial labels, skin colour and possession of both territory and bodies. The narrative shows different patterns of disrupted parenthood: the novel portrays the absence of parental figures as well as estrangement between family members, insincerity leading to the inability to communicate entangled with attempts to manipulate, and also physical and emotional violence. The disturbing patterns seem to pass from one generation to another: the characters appear to struggle when it comes to both building new, and sustaining already existing, relationships.

The Final Passage revolves around a young woman called Leila who throughout the narrative tries on different roles, starting with that of a daughter, then becoming a wife, and finally a parent. The narration in the novel is not linear; the non-chronological order corresponds to the state of the protagonist who continuously finds herself misplaced, both in the Caribbean and in England (Pichler 54). The non-linear manner also coincides with general tendencies in postcolonial writing which according to Ashcroft and his colleagues deviates from the dominance of the chronological view of events (Ashcroft et al., Key Concepts 8). Phillips does introduce a starting point to Leila's story in the second part of the text titled "Home": Leila is 19, living with her mother and preparing to get married. The protagonist's strongest bond remains the one with her only parent: the relationship of these two females, mother and daughter, simultaneously reflects the society and the colonial heritage of the island additionally providing an insight into the choices Leila makes as an adult later on.

Leila's father has been absent ever since she was born; both the main 
character and her mother seem to have agreed not to speak about him directly. The text does not state whether the father is known even to the mother herself, as Leila is described as belonging to all of her mother's lovers and to none of them. This notably weakens the ties of parenthood in The Final Passage: Leila is everyone's and no one's, dislocated and unable to find her roots. It appears that every now and then Leila would puzzle about her absent parent and the nature of the relationship which led to her birth but was repeatedly discouraged by the silence of her mother: "But her mother never said anything, and Leila used to look at her and wonder if her mother had ever been in love with her father, whoever he was" (65).

The omnipresent stillness kept by the mother and imposed on Leila already in her early childhood cripples the relationship between the two of them and later develops into an almost complete inability to communicate. The mother silently protects the identity of Leila's father as not even his first name is uncovered; neither does she reveal to her daughter that the actual parent might not be known at all. As a consequence, the only thing left is for Leila to make conclusions based solely on the colour of her own skin, so obviously different from that of her mother. However, even this seemingly obvious assumption is often interconnected with neglect, at least during Leila's childhood: being nicknamed as "mulatto girl", she would often run away and hide wishing for her mother to "tell her it was not true" (65).

What needs to be emphasised is that the writer employs a term which was specifically used to refer "to a slave who is one half white" (Ashcroft et al., Key Concepts 133). The racial label echoes back to a still existing parallel colony - metropole in a decolonised setting as it also shows how an expression, originally introduced by the European settlers, is adopted by the locals in order to bully a child born on a Caribbean island. By incorporating these labels Phillips exposes the uncomfortable realities of the heritage left by the British Empire: despite the proclaimed decolonisation, the community portrayed in The Final Passage is long used not only to mark people by the shade of their skin but to use it against them. Furthermore, it seems to be done rather negligently and mechanically, hardly taking into consideration possible consequences.

Moreover, the theme of skin and that of parenthood in the novel are closely tied: Leila's skin partially uncovers the truth hidden by her mother. The latter one is therefore unable to keep the matter contained regardless of how much she would have wished to: Leila's skin inevitably betrays her mother's past. Meanwhile, the daughter hopes for her only parent to reassure her, set 
her free of the mixed-race label put on her by other children. The mother's reply is silence, she neither provides an explanation nor assures the child of her origin; the presence of the father's figure(s), although muted, cannot be completely abolished as the shade of Leila's skin is a constant reminder of him to the remaining two members of the family. Both isolation and silence, just like the racial label, could be interpreted through the history of slavery in the Caribbean as the British imperial enterprise purposefully separated slaves from the place, the family and the language in order to limit possible rebellions (Ashcroft et al., The Empire Writes Back 144). Although Leila is raised by her kin, she is nevertheless denied full access to her past, alienated by her peers and continuously discouraged from sounding out her concerns and finding her voice; all of these she unwillingly brings into her adult life and projects onto the family she creates.

The Final Passage reveals that for a while Leila's mother continues taking money from three white males, convincing each of them of their relation to Leila, but forbidding any of the men to approach her: "these white men eyed their daughter from afar and happily paid the money safe in the knowledge that they had a real relationship with the island that would live on after they left" (126). The same extract points to how a territory could be possessed through bodies, especially through a female body. Such appropriation of the land is characteristic for both colonial and postcolonial discourses as "the body is a crucial site for inscription" (Ashcroft et al., Key Concepts 183). Another work dedicated to Caribbean literature, Anglophone Literature of Caribbean Indenture: The Seductive Hierarchies of Empire, also explores the ties of the land to female bodies, though mostly concentrating on fertility, yet still noting that those ties tended to "repeat colonial tropes" (Klein 177).

Phillips explicitly emphasises that the three men are content not with the fact of being parents but with being related to the island through the child whereas the child does not seem to matter on her own. In that regard Leila could be viewed as a mark on the map of the Caribbean left by the British colonisers, whereas her skin colour signifies the presence of the whites on the island and their conquest of its territory through possession and conquest of her mother's body. Although this possession was temporary, the birth of Leila permanently imprints the presence of the colonisers into the land, making the relationship with the island real as the child "would live on after they left". Lastly, while Leila might be insignificant on her own, her gender is certainly not treated as such: according to McClintock, a female is a symbolic bearer of the nation and therefore its reproducer (McClintock 354-5). 
The depiction of parenthood is disrupted on both sides: while all three men consider Leila to be their daughter, they find themselves comfortable in their absence from her life, quietly obeying Leila's mother and being content with providing nothing else but financial means. On the other hand, Leila herself is denied having even a shadow of a father as the real source of the money in the family is kept secret from her. To her father(s) Leila is a symbol worth paying for, whereas to her mother she is a good which is traded for financial stability; in both of these cases her personality and her character are completely disregarded and even irrelevant. Leila, without being aware of it, plays the role of merchandise while her mother decides to whom the parenthood should be sold, in one way or another assuming the role of a trader of sorts which once more reverberates with the colonial wounds of the West Indies.

Although to readers coming from a different background such a portrayal might seem bizarre, the novel reflects general tendencies of the region as Caribbean men have always been eager to claim paternity (Schwartz). An earlier work by Clarke states that "the proof of a man's maleness is the impregnation of a woman" (Clarke 96). Assigning paternity would fully depend on women as it would also give them a certain power; quite naturally, females, urged by their families, would choose whoever was able to support them the best (Barrow 33).

Despite this power, neither in the novel, nor in the studies mentioned, would women appear to be fully independent. Leila's mother, although living alone, could only do so because of the money provided by her exlovers. Recreational freedom also appears to be unavailable as the reality of having a child is imposed on Leila's mother rather than chosen. In fact, unwanted pregnancies were very often the case in the region where girls were purposefully kept in the dark when it came to sex education; abortions and contraception were both strongly disapproved of (Clarke $75^{-7}$ ).

Leila's mother's first sexual experience is described as abuse by a European man fifty years older who would lure her into the house for some errands and give her 10 cents after having forced himself onto the young woman; a depiction which could also be viewed as a sexualised idea of colonisation itself which is grounded in a discourse of "rape, penetration and impregnation" (Ashcroft et al., Key Concepts 36). Even though the woman's future sexual partners were more attentive and affectionate, once they leave Leila's mother would always feel like a "canvas upon which an artist has toyed in light pencil" (125). Feelings of being used and dismissed are additionally coupled with Leila's mother overall predicament and hostility towards white people 
despite (or rather because of) having several white men as lovers. Her distrust is especially evident in the episode where she finds her daughter laying on the beach with a white couple:

'Don't never let me catch you lying with white people again or as God's my witness I'll take a stick to you and beat you till the life leaves your body.' Leila stared at her, but this only spurred her mother on further. (129)

The character's readiness to be physically violent in order to prove her point exposes the depth of her distrust and suspicion as it also shows how far she is prepared to go to pass this hostility onto Leila. Whereas as a child she is perplexed by her mother's words, years after and away from her hometown Leila arrives at a very similar, bitter conclusion.

It is worth pointing out that relationships between black women and white men have been explored in several theoretical as well as fictional texts. In Black Skin, White Masks Fanon dedicated one chapter specifically to the topic. While analysing literary works together with his actual female acquaintances, Fanon notes that whereas black women only wished to turn white, a woman of a mixed-race origin would want "not only to turn white but also to avoid slipping back" (Fanon 38). Having a white parent is regarded as a privilege while marrying a black man is illogical and completely out of the question: "Get out of that and then deliberately go back to it? Thank you, no" (Fanon 36). As the author demonstrates in quoting a work by Mayotte Capécia, having white blood may change the perception: "I should have guessed it when I looked at her light color. I found her prettier than ever, and cleverer, and more refined" (Fanon 30).

Instead, in The Final Passage Phillips presents Leila in a completely different light as the protagonist never considers herself superior because of her skin nor attempts to further "bleach" herself (for example, by specifically looking for a white partner). Nevertheless, she is perceived differently in the Caribbean community, for instance, when describing the wedding between Leila and Michael, it is noted that the latter one "was a poor boy from this village and he was marrying the mulatto girl from St Patrick's. He had done well for himself" - it appears that to the eyes of the locals marrying a woman with lighter skin is something of an achievement (49).

Although marked by the community, Leila's personal life during her adulthood seems to escape the stereotype of some sort of superiority but only temporarily so. Leila's husband takes her for a woman convinced of 
being above the ordinary not only because she is better educated but also because of being partially white and therefore "a selfish, superior arse who think she do me a favour by marrying to me" (178). As a result, although the young woman does not fit Fanon's stereotype of a mixed-race female, she cannot altogether avoid it.

Leila's consequent journey to England further unveils and sharpens the growing uneasiness between the family members in the text. The travelling itself - from the island that used to be a colony to its previous metropole - also places Britain in the role of a motherland, which could be regarded as yet another disillusioning and dislocated parent, especially when it comes to hosting the postcolonial offspring. Although the main character is convinced that leaving the island might help to recover her broken marriage, in truth she would have never taken the trip if it had not been for her only parent. The protagonist follows her sick mother as she simultaneously travels to the metropole from what used to be a Caribbean colony just to find both England and her mother in a hopeless, irreversibly diseased state. Leila's visits to hospital where her parent is staying are overlapped with harsh realities the main character encounters as a newly-arrived migrant: she quickly discovers the many prejudices towards black people, the visible segregation in terms of jobs one could hope to find and places to rent.

The English space pictured by Phillips echoes the portrayal given by Rushdie where he labels Britain as the last colony of the British Empire, emphasising that white superiority which ruled over dependent territories did not vanish but "seeped into every part of the culture, the language and the daily life" (Rushdie 130). However, while The Final Passage does point to a number of issues, the essays from Imaginary Homelands go much further and depict physical and mental abuse of black people, the fear of going out after dark and threats from the police (Rushdie 131-4). Instead, the portrayal provided by Phillips is less graphic but concerning nonetheless: the first nights in London Leila sleeps in a bathtub with her son, having discovered that her mother could only afford a dark, draughty room in an apartment rented out to other migrants.

Such representation is strikingly similar to the one given in This is London: Life and Death in the World City. While in his book Judah introduces the readers to a Nigerian police officer stating that "London can crush you... Or London can transform you. You can rise up here. The white people, they are not stopping you", he simultaneously interviews tenants of an illegal boarding 
house with one bathroom is shared between fourteen people (Judah 53). Although soon enough Leila manages to rent a small house, Phillips makes it clear that it is only because the real estate agent meets Leila alone, instead, when she is accompanied by her husband, all the places turn the young family down.

Throughout the text the protagonist is continuously forced to be labelled and treated according to her skin colour in both spaces she inhabits; she does not seem to reflect on her own predicament towards white people. Leila absorbs her mother's words about white women and as the mother's warning reverberates in her daughter's adult life, it does not help Leila; instead, it blurs her perception as it leads her to the point where she loses the only friend she had made in England. Wrongly convinced of the reasons behind her husband's infidelity and blaming herself more than anyone else, Leila pushes away her neighbour, Mary, one of the few characters sincerely interested in Leila during her stay in London. Mary also seems to appropriate the role of a mother but her kind intentions are neglected by Leila who becomes convinced of her neighbour's hostility, which is tightly connected with her mother's warning: "Even without knowing it Mary might hurt her in some way, for she had come too close to Leila, and Leila cursed herself for being foolish enough to allow this to happen" (198).

As hopes for a better life in the English space gradually fade away, the same happens with Leila's illusions of having a functioning relationship with her actual parent who purposefully and continuously demonstrates: "no sign that the relationship Leila had dreamed of for so long would ever materialize" (175). The dysfunctional relationship mirrors the colonialist system which throughout decades allowed an "idea of improvement for the colonized, via such metaphors as parent/child [...] which in theory allowed that at some future time the inferior colonials might be raised to the status of the colonizer" (Ashcroft et al., Key Concepts 42-3).

Instead, in practice, such a future was continuously postponed, a metaphor similar to the one which Phillips employs when portraying Leila's elusive relationship with her parent. The Final Passage repetitively brings up Leila's attempts to be elevated in her mother's eyes, the attempts which always prove to be unsuccessful and are followed by bitter disappointment. The constant distress of the young woman is hardly noticed by anyone, throughout the text the protagonist remains a traumatised subject of both violence and identity crisis, her feelings and emotions are either ignored or normalised and 
immediately dismissed (Ledent 5). Moreover, while the rest of the characters act as both victims and aggressors, Leila remains mostly passive: she is traded and paid for, abused, turned down and denied equality and partnership.

The stillness in the family, always chosen over an open confrontation, results in a complete failure to communicate emotions, shutting them down instead. The birth of Leila's son, Calvin, does not bring the mother and daughter closer and neither do the numerous experiences they both go through: "The pain of illness, the pain of marriage, the pain of a journey across the world and the happiness of a small baby for them both to share, nothing seemed to be able to bring them together" (124).

Leila is unable to admit and confess how ruined her marriage truly is as her mother is unable to console her, although she seems to be aware of exactly what her daughter is going through. The acceptance and even encouragement of men's abusive behaviour in the region are clearly reflected in The Final Passage; indeed, the last conversation two women have before the mother's death, is entirely dedicated to male violence: "Michael beat you yet, girl?' she had asked, as if asking for a glass of water." and instead of giving an answer Leila "had smiled weakly, as if it was nothing to do with her, a good story well told, and her mother had smiled back at her in a different fashion" (131). Leila is forced to exist within the frames imposed on her, without being fully aware of the rules, whereas her mother knows the situation all too well, replying with a smile of "a different fashion" and treats it casually - "as if asking for a glass of water" - yet refuses to guide or even to comfort her own child (131; emphasis added).

The mother's departure from the Caribbean comes to Leila suddenly and unannounced, planned and prepared without being spoken of, and so does her death, surrounded by the silence kept by the doctor and the nurse as well as the mother herself. Although never really close to her only parent, Leila now has to give up her illusion of forming a trusting relationship with her mother once and for all; the illusion which the protagonist carried with her during her entire life and which brought her across the Atlantic can no longer exist: "Didn't they understand that she barely knew her mother, that everything up until now had been a preparation for knowing, not the knowing itself. Her mother was almost a stranger, and even after four months in England Leila had never given up hope that she might still get to know her" (132; emphasis added).

Together with the body of her parent and her shattered illusion of building trust with her mother, Leila buries "the dream of a rich father" (182). This line 
of The Final Passage very much resembles Fanon's statement that historically white dominance has been "felt economically" (Fanon 29). The conviction that "[o]ne is white above a certain financial level" seems to be encoded into Leila without her awareness of it: having concluded that her father is a white man, she immediately presumes that her father is also rich (Fanon 30). This assumption is strengthened by the fact that while living in the Caribbean Leila would never have to worry about money, and further fortified by her mother keeping the financial sources secret. Learning that money-wise her father left her no inheritance once and for all distances Leila from him: her father failed to be a part of her life just like he failed to give her and her own family a financially secure future.

No longer having to visit the hospital and unable to work because of her second pregnancy, Leila dedicates her time to her son though in an absentminded way, as if not having a better alternative of how to spend her long days in London. The matter of skin colour is present also in this new generation: Calvin is noted for his black skin from birth as the nurse who came to Leila's house remarks that "The child dark like Shere. Much darker than you" (73). Similarly to how Leila's skin does not resemble that of her mother, the colour of Calvin's skin is different from hers. Furthermore, in England because of the colour of his skin, Calvin sometimes is not recognised as Leila's son, especially when it comes to people on the outside for whom the ties between Leila and Calvin might not always be obvious.

Just like his mother in the Caribbean, Calvin too has troubles identifying himself in the space of predominantly white London, as soon as he can express himself: "Why is Santa Claus white?" he asks Leila who is unable to give an explanation, never having received an answer as to why she was nicknamed "mulatto girl" (202). Yet, however rootless on her father's side, Leila grew up having the community of the island around, whereas Calvin is raised by his mother alone. Leila has no alternative but to pass onto her son her own unbelonging which deepens in this new generation even more: surrounded mostly by white neighbours and barely seeing his father, Calvin cannot place himself within the unwelcoming space of postcolonial England where "white and black perceptions of everyday life have moved so far apart as to be incompatible" (Rushdie 135).

Leila's overall relationship with Calvin appears to be entangled rather than simple: although the main character does care about her son, throughout the narrative she appears to simultaneously use him, sometimes as protection, sometimes as a comfortable excuse. In the Caribbean children assisted with 
tasks to help run the household as soon as they were old enough, in general, for a family having children would mean additional labour, for instance, in Barbuda, "by the time a girl is eleven or twelve she can run a household and often does" (Schwartz). It is therefore possible to suggest that Leila's childhood was not much different; the protagonist's relationship with Calvin could be interpreted as an attempt to break the established pattern and surround the youngest member of the family with care and attention. However, while Leila provides for the child's needs, their routine is deprived of practically any kind of activity which would bond the two of them together or create a happy childhood; caring for Calvin does not seem to go further than feeding and dressing him. For instance, The Final Passage never pictures Leila playing with her son, their days are all strikingly similar, a chain of dull, somewhat aimless and repetitive actions:

Leila got up, made Calvin his breakfast, waited for the postman to bring nothing, thought of Michael, read a page or two of a book, walked in the cold to her mother's grave, came back, made Calvin something else to eat, then sat in the gloom waiting for it to get dark before going to bed. This was her life. (196)

The overall portrayal of the mother-son relationship gives the impression of Calvin not being treated as a child but more like a doll of sorts: Leila constantly keeps him close, clinging to him and seeming to be somehow unable to part with him. The protagonist clearly feels uneasy also when her son is touched by other people: every time when Miss Gordon, the social worker, holds Calvin, Leila is strangely convinced that "it was done to see if his skin colour was invented or real" (199).

The monotonous, repetitive days result in the character of Leila being hardly awake at all by the end of the novel, behaviour which could be regarded as a refusal of assimilation to the surroundings, the only accessible way to oppose the order imposed onto the character (Ledent 3 ). Though this kind of attitude was at least partially triggered by the death of her mother combined with financial difficulties and a serious marriage crisis, Leila acts similarly also when she is in her hometown. Left by her husband immediately after her wedding, she crawls into her bed and hardly gets out for two days in a row, her continuous distress remaining to be unnoticed and unremarked.

In England the passive, drowsy days stretch into weeks and then into 
months. Neither is Calvin depicted to be lively, despite being a small and healthy boy. It seems like the best thing Leila can think of for her child to do is constant sleeping, no matter the time of day: "Leila made Calvin his breakfast, then tried to encourage him to sleep"; towards the very end of the text, the boy is described to be silently playing with himself, apparently quite used to it (200). Just like Leila, Calvin is destined to grow up fatherless. Michael, who at first seems to use the house in London as a place to sleep and change, soon disappears completely, leaving his family alone and financially broken, his wife pregnant and unable to pick up a job which would allow her to support herself.

Although the narrative focuses on Leila, the readers also learn that Michael has an illegitimate son, Ivor, from a woman called Beverley. Leila, though aware of the other family before her marriage with Michael, does not care to pay attention to Beverley's and Ivor's existence nor give them any importance whatsoever, somewhat bluntly convinced she would be treated differently:

'You think she don't be nothing because her man done leave she?'

'What are you talking about, Millie?'

'You think like man now, you think she just be something (6o)

Leila's conviction turns out to be gravely wrong as Michael is equally absent from the lives of both of his sons: neither Calvin nor Ivor means anything to him. Neither of the children was planned, Michael seems to perceive his sons as merely an unlucky consequence of having unprotected sex, hardly feeling any responsibility towards his offspring. His character is equally displeased when Leila's pregnancy starts to show and annoyed when Ivor cries, reminding his presence to his father during his visits to Beverley. Although to Michael the number of sexual partners as well as the number of children is a matter of pride, he hardly thinks about any of them. Instead, his character openly enjoys being a male on the island, leading "a parasitic existence in various places" (Pichler 55).

Unlike his wife, Michael hardly sees his trip to England as an opportunity to repair his marriage and to be at last reunited with his spouse and son; instead, London triggers Michael's ambitions in his attempt to be successful and to make something out of himself. Although similarly to Leila Michael recognises his marginalised position in the social hierarchy in the space of England, he is nevertheless convinced of having the abilities to overcome the 
difficulties (Ashcroft et al., Key Concepts 213). Within months after his arrival to London the character declares his wish to become an entrepreneur while treating Leila and Calvin as unnecessary accessories even more evidently so than in the Caribbean. At last, Michael begins to see both his wife and his son as obstacles on his path to a better life. Although he angrily shouts at Leila: "'So you don't think I'm interested in Calvin or what?' . . 'You don't think that what I'm planning is for the benefit of my son or what!', the narrative makes it clear that once gone, Michael would not appear again (177).

To draw a conclusion, through the theme of parenthood Phillips explores a variety of topics, simultaneously commenting on the patterns characteristic to the Caribbean and touching upon the uneasiness of the decolonisation period. Perhaps this might be the reason why the author's portrayal is a complicated one: marginalised communities, economic and housing issues are intertwined with personal challenges and broken hopes. Nearly all the relationships turn out to be dysfunctional and disillusioning, including the bond between the mother and daughter figures which appears to be the most unfulfilling of all. Lack of trust and intimacy together with emotional distress in the mother-daughter relationship mirror Phillips's description of England: a cold, unwelcoming place which fails to fulfil the expectations of its postcolonial offspring.

Similarly to how the new generation of Caribbean authors continue to revisit the wounds of the colonial era, unable to find closure, Phillips concludes the text with an open ending, letting Leila become another neglected exile trapped in the past. Even though at the very end her character, having given up her hopes for both her mother and the motherland, dreams of going back to the Caribbean where her children might find a welcoming home and a community they could belong to, the finale of the novel portrays the protagonist locking herself once again in the gloomy, draughty house. Although signalling the problems which remain to be all the more relevant for the Caribbean community, Leila's story does not become a symbol of hope nor that of resistance: left by her husband and having no financial means, the young woman is alone and broken, with no energy to break free from the established routine.

\section{Works Cited}

Ashcroft, Bill, Gareth Griffiths, and Helen Tiffin. Key Concepts in Post-Colonial Studies. London \& New York: Routledge, 2nd ed., 2007. 
Ashcroft, Bill, Gareth Griffiths, and Helen Tiffin. The Empire Writes Back. London \& New York: Routledge, 2nd ed., 2002.

Barrow, Christine. Children's Rights: Caribbean Realities. Kingston: Ian Randle, 2002.

Bewes, Timothy. "Shame, Ventriloquy, and the Problem of the Cliché in Caryl Phillips." Cultural Critique, no. 63, 2006, pp. 33-6o. FSTOR, https://www. jstor.org/stable/4489246

Clarke, Edith. My mother who fathered me: A study of the family in three selected communities in Famaica. London: George Allen \& Unwin, 1957.

Fanon, Frantz. Black Skin, White Masks. London: Pluto Press, 1986.

Goddard, Horace I. "Travel discourse in Caryl Phillips's The Final Passage and A State of Independence." Kola, no. 21, 2001, pp. 149-162.

http://go.galegroup.com/ps/i.do?id=GALE\%7CA2O4205462\&v=2.1\&u=p alacky\&it=r\&p=LitRC\&sw $=w$

Judah, Ben. This is London: Life and Death in the World City. London: Picador, 2016.

Kato, Tsunehiko. "Caryl Phillips as a Black British Writer: The Experience of Caribbean Immigrants After World War II." Ritsumeikan Annual Review of International Studies, no. 1, 2002, pp. 121-132. http://www.ritsumei.ac.jp/ ir/isaru/assets/file/raris/raris-o1-8kato.pdf

Kirkbride, James B. et al. "Ethnic Minority Status, Age-at-Immigration and Psychosis Risk in Rural Environments: Evidence From the SEPEA." Study Maryland Psychiatric Research Center and Oxford University Press, vol. 43 , no. 6, November 2017, pp. 1251-1261. https://academic.oup.com/ schizophreniabulletin/article/43/6/1251/3829518?login=true

Klein, Alison. Anglophone Literature of Caribbean Indenture: The Seductive Hierarchies of Empire. London: Palgrave, 2018.

Ledent, Bénédicte, O’Callaghan, Evelyn, and Tunca, Daria. Madness in Anglophone Caribbean Literature. London: Palgrave, 2018.

McClintock, Anne. Imperial Leather. London \& New York: Routledge, 1995. Phillips, Caryl. The Final Passage. London: Picador, 1985.

Pichler, S. "Alien-Nation and Belonging: Ethnic Identities in Selected Black British Novels." AAA: Arbeiten aus Anglistik und Amerikanistik, vol. 29, no. 1, 2004, pp. 43-63. JSTOR. https://www.jstor.org/stable/43025719

Rushdie, Salman. Imaginary Homelands. London: Granta Books, 1991.

Schwartz, Timothy T. Explaining Caribbean Family Patterns. Schwartz Research Group, Dec. 2016. https://timothyschwartzhaiti.com/caribbean-familypatterns/ 
Smith, Craig A. "Migration, Manhood and Melancholia in the Work of Caryl Phillips." Journal of West Indian Literature, vol. 24, no. 1, April 2016, pp. 27-45. FSTOR, https://www.jstor.org/stable/jwestindilite.24.1.27.

ANASTASIIA FEDIAKOVA, a recent MA graduate of the Department of Anglophone Literatures and Cultures, Charles University, Prague, is currently preparing for her future $\mathrm{PhD}$ studies. She is primarily interested in Postcolonial Discourse and Global Literature. Her latest publication explores the short stories of Jhumpa Lahiri and Kazuo Ishiguro and concentrates on food habits in connection with identity. Aside from her studies, she teaches foreign languages and translates.

anastasiia.fediakova@gmail.com 